\title{
The most important medicinal plants affecting sperm and testosterone production: a systematic review
}

\author{
Shakiba Nasiri Boroujeni ${ }^{1 a}$, Farid Ansari Malamiriza, Fatemeh Bossaghzadeh ${ }^{3}$, Alireza Esmaeili ${ }^{4}$, Emadoddin \\ Moudi $^{*}$ \\ ${ }^{1}$ Medical Plants Research Center, Basic Health Sciences Institute, Shahrekord University of Medical Sciences, \\ Shahrekord, Iran \\ ${ }^{2}$ Faculty of Veterinary Medicine, Islamic Azad University of Shahrekord, Shahrekord, Iran \\ ${ }^{3}$ Department of Biology, Dezful Branch, Islamic Azad University, Dezful, Iran and Student Research Committee, \\ Dezful Branch, Islamic Azad University, Dezful, Iran \\ ${ }^{4}$ Non-Communicable Disease Research Center, Ilam University of Medical Sciences, Ilam, Iran \\ ${ }^{5}$ Associate Professor, Department of Urology, Cancer Research Center, Health Research Institute, Babol Univer- \\ sity of Medical Sciences, Babol, Iran \\ aThese authors considered as first author
}

\begin{abstract}
Objective: Infertility, defined as the inability to conceive after one year of intercourse without the use of contraception, affects $15 \%$ of couples. Many factors, such as genitourinary tract infections, endocrine disorders, immunological factors and drug-related injuries, affect the male reproductive system and cause infertility. Due to men's fear of infertility, it is very important to pay attention to medicinal plants that are effective in male fertility. Therefore, the aim of this study was to evaluate the medicinal plants that affect sperm and testosterone production in men.
\end{abstract}

Methods: In this review, we used the following search terms, consisting of herbal medicine, traditional medicine, traditional therapies, sperm, testosterone, testicles and Iran were used to retrieve the relevant articles published in the journals indexed in the Information Sciences Institute, Science Direct, PubMed, Scopus, PubMed Central and Scientific Information Databases. We searched and used papers published between 2000 and 2020. Then, we analyzed the eligible papers. We collected and analyzed 35 papers from the databases. We selected only the articles about herbs that affect sperm and testosterone production.

Results: Based on the results, herbs Apium graveolens, Cinnamomum camphora, Cornus mas, Satureja khuzestanica, Withania somnifera, Fumaria parviflora, zingiber officinale, cinnamomum zeylanicum and Phoenix dactylifera are used in the male reproductive system.

Conclusions: Plants can probably be useful in increasing fertility due to their antioxidant power and low side effects.

Keywords: sperm production, testosterone, herb, traditional medicine, testicles, Iran

\section{INTRODUCTION}

Infertility, defined as the inability to conceive after one year of intercourse without the use of contraception, affects $15 \%$ of couples (Kim et al., 2013). About $30-50 \%$ of infertility is related to male infertility and $30-40 \%$ of the causes of male infertility are related to sperm disorders (Godmann et al., 2009). The most common cause of infertility in men is their inability to produce enough healthy, active, and highly motile sperm (Bastampoor et al., 2014; Oyeyemi et al., 2008). Lack of testicular development, diseases of the reproductive system, increased scrotal temperature, immunological problems, endocrine disorders, lifestyle choices, environmental and nutritional factors are considered as the main causes of male infertility having a negative effect on sperm parameters (Marbeen et al., 2005; Sharpe \& Franks, 2002; Low et al., 2013; Singh \& Jemal, 2017; Chyou et al., 1993; De Rosa et al., 1981). Many factors, such as genitourinary tract infections, endocrine disorders, immunological factors, and drug-related issues, affect the male reproductive system and cause infertility (Wang et al., 2018; Jiang et al., 2017; Kesari et al., 2018; Agarwal et al., 2018). Disorders affecting spermatogenesis, hormone regulation, oxidative stress, and regulation of spermatogenesis-related genes cause infertility (Zhou et al., 2019; Moghbelinejad et al., 2018; Zhang et al., 2020; Hu et al., 2006; Ma et al., 2015). Infertility can be due to excessive consumption of natural plant compounds (phytoestrogens). These compounds can affect the reproductive system and reduce fertility (Csupor-Löffler et al., 2009). Sperm plasma membranes are exposed to oxidative damage due to large amounts of unsaturated fatty acids, which ultimately decrease sperm motility and viability. Antioxidant compounds increase sperm function and can improve fertility (Kooti et al., 2014).

According to several studies, oxidative stress can cause molecular and genetic defects causing infertility (Agarwal et al., 2006). Oxidative stress is usually associated with aerobic metabolism producing prooxidant molecules or reactive oxygen species (ROS). Some cells have specific mechanisms for producing the ROS required for cellular function at low concentrations. Depending on the tissue concentration of ROS, they can have beneficial physiological effects and play a role in the fertilization process. Free radicals can affect the ova, sperm, and embryos in their small environment. Free radicals can also damage cellular components, including lipids, proteins, and nucleic acids. There is a complex interaction of cytokines, hormones and other stressors that affect the production of free radicals (Gupta et al., 2007). ROS can be neutralized by a complex antioxidant defense system consisting of enzymes such as catalase, superoxide dismutase and glutathione peroxidase/reductase, and several non-enzymatic antioxidants such as vitamin $C$, vitamin E, vitamin A, pyruvate, glutathione, taurine (Safarnavadeh \& Rastegarpanah, 2011). Whenever the level of ROS is pathologically elevated, antioxidants begin to work, helping to minimize oxidative damage, repair, or prevent it. The male and female reproductive organs are rich in both enzymatic and non-enzymatic antioxidants. Increased ROS levels can damage 
the ovum, the zygote/embryo, and most importantly, the sperm. Sperm are very sensitive to oxidative stress. Oxidative stress appears to be due to increased ROS production rather than a decrease in antioxidants (Safarnavadeh \& Rastegarpanah, 2011). The WHO recommends the use of traditional medicines in the medical health care system. However, there has been a great deal of interest in finding natural antioxidants from herbal materials to replace synthetic drugs recently (Hasani-Ranjbar et al., 2009). There are many medicinal plants in the world with anti-fertility and fertility-enhancing properties (Jain et al., 2015; Modaresi et al., 2008). Many people now use herbs or their derivatives to increase or decrease fertility as well as libido (Kachroo \& Agrawal, 2011). Some of these plants have spermicidal properties, others increase the number of sperm and change sperm motility. Some plants also alter testicular hormones (Khaki et al., 2014).

The World Health Organization reports that despite the increasing use of herbal medicines, there is still a significant lack of research on it, and the role of studies examining herbal medicines is crucial. Due to the clear negative effects of chemical drugs on humans, the tendency to use herbal medicines is increasing among women and men. We need to study the use of biologically active plant materials in the field of male fertility and to identify natural plant materials with estrogenic and anti-estrogenic properties (Marbeen et al., 2005). Due to men's fear of infertility (Hosseini \& Abdi, 2012), it is very important to pay attention to medicinal plants that affect male fertility. Therefore, the aim of this study was to evaluate the medicinal plants that affect sperm and testosterone production in men.

\section{MATERIALS AND METHODS}

We used the following search terms: herbal medicine, traditional medicine, traditional therapies, sperm, testosterone, testicles and Iran, to retrieve the relevant papers published in the journals indexed in the Information Sciences Institute, Science Direct, PubMed, Scopus, PubMed Central and Scientific Information Databases. Papers published in 2000-2020 were searched and used in the review. Then, we analyzed the findings of the eligible papers.

We assessed the abstracts for the pre-determined inclusion and exclusion criteria. We collected 35 papers from the databases, and 15 papers were taken out due to repeatability, irrelevance, lack of a summary, non-native Iranian plants, invalid papers and invalid journals. Papers without an abstract in English, without a full text and books were excluded from the analysis. Only the papers about herbs that affect sperm and testosterone hormone production were selected for the study (Flowchart 1).

\section{RESULTS}

According to the analysis, 9 medicinal plants were found to affect the male reproductive system. Table 1 enlists some effective medicinal plants, their families,
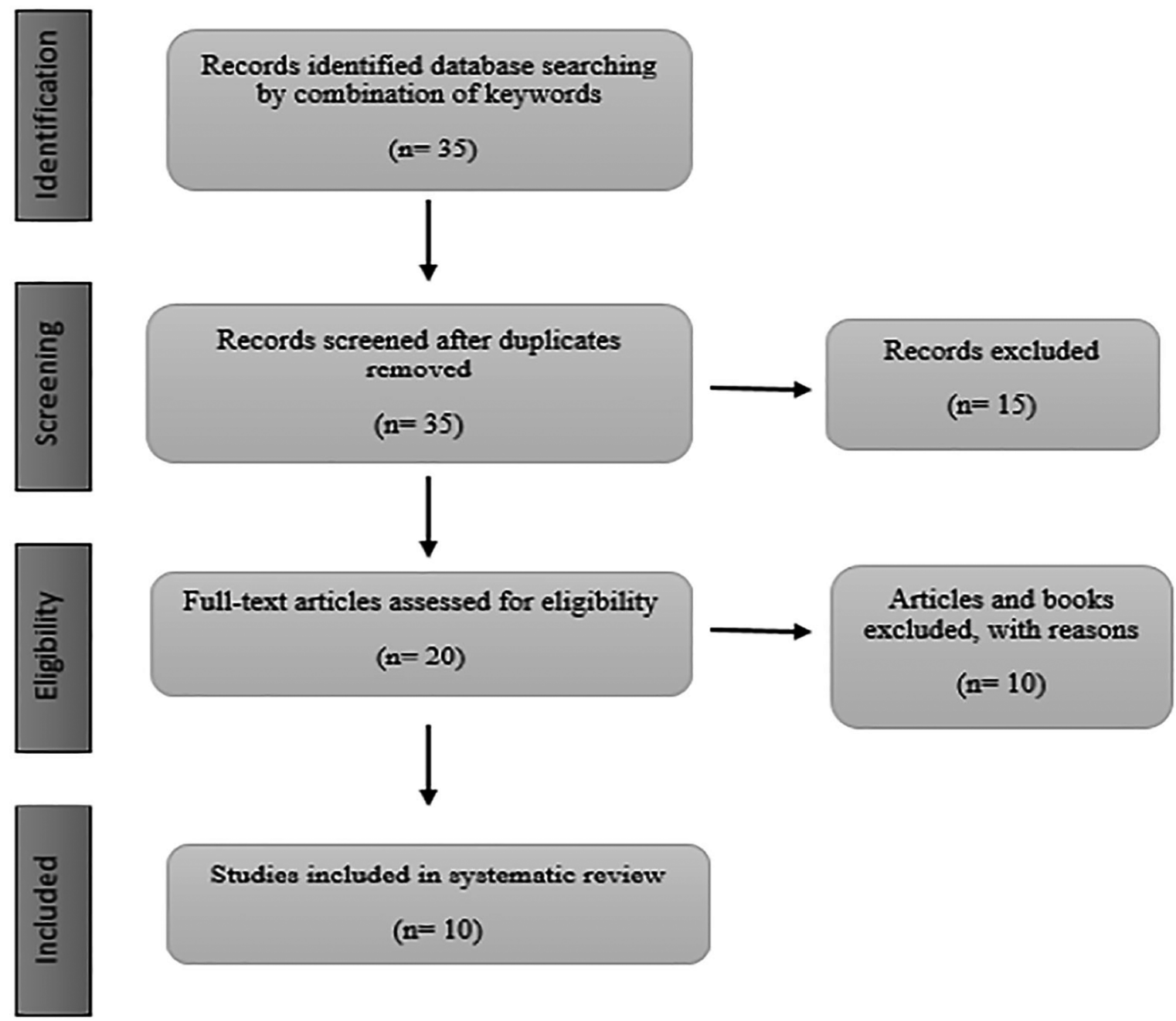

$(n=20)$

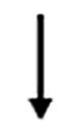

Studies included in ryatematic reviow

$(n=10)$

Flowchart 1. The criteria and the number of included and excluded articles. 
Table 1. The list of medicinal plants affects male reproductive system.

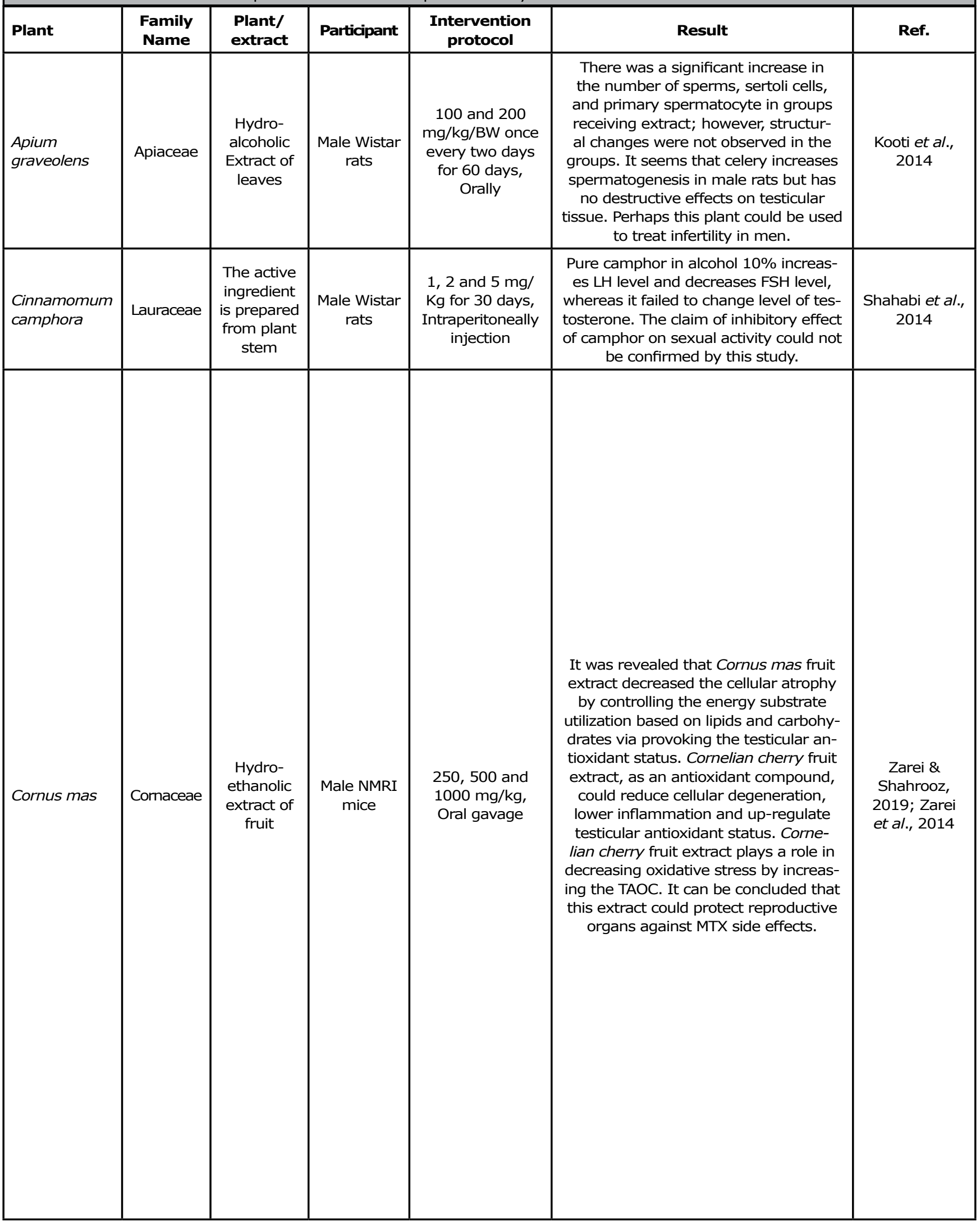


Continued Table 1.

\begin{tabular}{|c|c|c|c|c|c|c|}
\hline $\begin{array}{l}\text { Satureja } \\
\text { khuzestanica }\end{array}$ & Lamiaceae & $\begin{array}{l}\text { Essential } \\
\text { oil of aerial } \\
\text { parts }\end{array}$ & $\begin{array}{c}\text { Male Wistar } \\
\text { and Albino } \\
\text { rats }\end{array}$ & $\begin{array}{c}75,150,225 \\
\mathrm{mg} / \mathrm{kg} / \text { day for } \\
45 \text { days and } 225 \\
\mathrm{mg} / \mathrm{kg} / \text { day for } 28 \\
\text { days, Orally }\end{array}$ & $\begin{array}{c}\text { Significant improvements in potency, } \\
\text { fecundity, fertility index, and litter size and } \\
\text { significant decrease in post implantation } \\
\text { loss. Satureja khuzestanica essential } \\
\text { oil protected reproductive system from } \\
\text { toxicity of Cyclophosphamide through } \\
\text { its antioxidant potential and androgenic } \\
\text { activity. }\end{array}$ & $\begin{array}{c}\text { Safarnavadeh } \\
\text { \& Rastegar- } \\
\text { panah, } 2011 \\
\text { Haeri et al., } \\
2006 \\
\text { Rezvanfar et } \\
\text { al., } 2008\end{array}$ \\
\hline $\begin{array}{l}\text { Withania } \\
\text { somnifera }\end{array}$ & $\begin{array}{l}\text { Solana- } \\
\text { ceae }\end{array}$ & $\begin{array}{l}\text { Hydro-al- } \\
\text { coholic and } \\
\text { aqueous } \\
\text { extract and } \\
\text { powder of } \\
\text { all parts } \\
\text { mostly root }\end{array}$ & $\begin{array}{l}\text { Human, } \\
\text { cell, mice } \\
\text { and rat }\end{array}$ & $\begin{array}{l}\text { Different doses } \\
\text { and most inter- } \\
\text { vention } \\
\text { protocol }\end{array}$ & $\begin{array}{c}\text { It deems that Withania somnifera has a } \\
\text { positive effect in the treatment of infer- } \\
\text { tility both in male and female. Although } \\
\text { some studies proposed that WS extract } \\
\text { might have non-fertilizing and spermi- } \\
\text { cidal effect. }\end{array}$ & $\begin{array}{c}\text { Nasimi Doost } \\
\text { Azgomi et al., } \\
2018\end{array}$ \\
\hline $\begin{array}{l}\text { Fumaria } \\
\text { parviflora }\end{array}$ & $\begin{array}{l}\text { Papavera- } \\
\text { ceae }\end{array}$ & $\begin{array}{l}\text { ethanolic } \\
\text { extract of } \\
\text { leaves and } \\
\text { powder }\end{array}$ & $\begin{array}{l}\text { Male Wistar } \\
\text { rats }\end{array}$ & $\begin{array}{l}200 \mathrm{mg} / \mathrm{kg} \mathrm{day}^{1} \\
\text { gavage for } 70 \\
\text { days }\end{array}$ & $\begin{array}{l}\text { The results indicated that ethanolic } \\
\text { extract of } F \text {. parviflora leaves has po- } \\
\text { tential to restore the suppressed repro- } \\
\text { duction associated with lead exposure } \\
\text { and prevented lead-induced testicular } \\
\text { toxicity in male Wistar rats. }\end{array}$ & $\begin{array}{c}\text { Dorostghoal et } \\
\text { al., } 2014\end{array}$ \\
\hline $\begin{array}{l}\text { zingiber offic- } \\
\text { inale }\end{array}$ & $\begin{array}{l}\text { zingibera- } \\
\text { ceae }\end{array}$ & $\begin{array}{l}\text { Ginger } \\
\text { roots pow- } \\
\text { dered and } \\
\text { dissolved } \\
\text { in } 2 \mathrm{cc} \\
\text { distilled } \\
\text { water }\end{array}$ & $\begin{array}{l}\text { Male Wistar } \\
\text { rats }\end{array}$ & $\begin{array}{c}100 \mathrm{mg} / \mathrm{kg} \\
\text { gavage method, } \\
\text { daily for, } 8 \text { weeks }\end{array}$ & $\begin{array}{l}\text { The application of ginger plus } \\
\text { Cinnamon compared with ginger and } \\
\text { cinnamon alone in diabetic rats signifi- } \\
\text { cantly improved the damaging effects } \\
\text { of oxidative stress on spermatogenesis } \\
\text { and fertility parameters. It seems that } \\
\text { the antioxidant content of herbs could } \\
\text { be increased dramatically when used in } \\
\text { combination. }\end{array}$ & $\begin{array}{c}\text { Khaki et al., } \\
2014\end{array}$ \\
\hline $\begin{array}{l}\text { cinnamomum } \\
\text { zeylanicum }\end{array}$ & lauraceae & $\begin{array}{l}\text { Cinnamon } \\
\text { zeylanicum } \\
\text { powdered } \\
\text { and dis- } \\
\text { solved in } \\
\text { 2cc distilled } \\
\text { water }\end{array}$ & $\begin{array}{l}\text { Male Wistar } \\
\text { rats }\end{array}$ & $\begin{array}{c}75 \mathrm{mg} / \mathrm{kg} \\
\text { gavage method, } \\
\text { daily for, } 8 \text { weeks }\end{array}$ & $\begin{array}{l}\text { The application of ginger plus } \\
\text { Cinnamon compared with ginger and } \\
\text { cinnamon alone in diabetic rats signifi- } \\
\text { cantly improved the damaging effects } \\
\text { of oxidative stress on spermatogenesis } \\
\text { and fertility parameters. It seems that } \\
\text { the antioxidant content of herbs could } \\
\text { be increased dramatically when used in } \\
\text { combination. }\end{array}$ & $\begin{array}{c}\text { Khaki et al., } \\
2014\end{array}$ \\
\hline $\begin{array}{l}\text { Phoenix } \\
\text { dactylifera }\end{array}$ & $\begin{array}{l}\text { Arecace- } \\
\text { ae }\end{array}$ & $\begin{array}{l}\text { extract of } \\
\text { fruit }\end{array}$ & $\begin{array}{l}\text { Human, } \\
\text { rat, mice, } \\
\text { rabbit, and } \\
\text { hamster }\end{array}$ & $\begin{array}{l}\text { Different doses in } \\
\text { different routes }\end{array}$ & $\begin{array}{l}\text { This review showed that phoenix dac- } \\
\text { tylifera pollen is a very suitable supple- } \\
\text { ment for infertility and can reduce free } \\
\text { radicals and increase sperm motility. }\end{array}$ & $\begin{array}{l}\text { Abdi et al., } \\
2017 \\
\text { Fallahi et al., } \\
\quad 2015\end{array}$ \\
\hline $\begin{array}{l}\text { Plukenetia } \\
\text { conophora }\end{array}$ & $\begin{array}{l}\text { Euphor- } \\
\text { biaceae }\end{array}$ & $\begin{array}{l}\text { methanolic } \\
\text { extract }\end{array}$ & $\begin{array}{l}\text { Male Wistar } \\
\text { rats }\end{array}$ & Different doses & $\begin{array}{l}\text { Olaniyan et al. In } 2018 \text { to evaluate } \\
\text { the effects of Plukenetia conophora } \\
\text { (PC) and } 4 \mathrm{H}-\mathrm{Py} \text { ran-4-One 2,3-Dihy- } \\
\text { dro-3,5-Dihydroxy-6-Methyl (DDMP) } \\
\text { on Wistar rats with chloride-induced } \\
\text { testicular damage Cadmium (CdCl2). } \\
\text { Treated daily for } 54 \text { days. Methanolic } \\
\text { extract of Nigeria fruit seeds was used. } \\
\text { Thus: control group (normal saline). } \\
\mathrm{CdCl} 2 \text { ( } 2 \mathrm{mg} / \mathrm{kg} \text { single dose IP); CdCl2 } \\
+200 \mathrm{mg} / \mathrm{kg} \text { vitamin E; CdCl2 }+100 \\
\text { or } 200 \mathrm{mg} / \mathrm{kg} \mathrm{PC;} \text { And CdCl2 + } 25 \\
\text { or } 50 \mathrm{mg} / \mathrm{kg} \text { DDMP. The biochemical } \\
\text { parameters of malondialdehyde, nitric } \\
\text { oxide, antioxidant enzymes and proton } \\
\text { pumps were measured by spectro- } \\
\text { photometry. Reproductive hormones } \\
\text { were measured using ELISA. In the } \\
\text { treated groups, a significant increase in } \\
\text { sperm count, motility and viability was } \\
\text { observed. Malondialdehyde and nitric } \\
\text { oxide levels were significantly reduced. } \\
\text { Significant increases in antioxidant en- } \\
\text { zymes, proton pump and testosterone } \\
\text { were observed in the treated groups. }\end{array}$ & $\begin{array}{l}\text { Olaniyan et } \\
\text { al., } 2018\end{array}$ \\
\hline
\end{tabular}


Continued Table 1.

\begin{tabular}{|l|c|c|c|c|c|c|}
\hline Garcinia kola & $\begin{array}{c}\text { Clusiace- } \\
\text { ae }\end{array}$ & $\begin{array}{c}\text { ethanolic } \\
\text { extract }\end{array}$ & $\begin{array}{c}\text { Adult male } \\
\text { Wistar rats }\end{array}$ & Different doses & $\begin{array}{c}\text { It has been concluded that Garcinia } \\
\text { cola and vitamin E show liver protection } \\
\text { against oxygen free radicals produced } \\
\text { by lead ions by maintaining the tissue } \\
\text { integrity of rat testis. }\end{array}$ & $\begin{array}{c}\text { Dare } \text { et al., } \\
2014\end{array}$ \\
\hline $\begin{array}{l}\text { Cocos nucif- } \\
\text { era } L\end{array}$ & $\begin{array}{c}\text { Arecace- } \\
\text { ae }\end{array}$ & Oil & $\begin{array}{c}\text { Adult male } \\
\text { Wistar rats }\end{array}$ & Different doses & $\begin{array}{c}\text { Cocos nucifera oil reduces the harmful } \\
\text { effects of lead acetate in male Wistar } \\
\text { rats, which may be due to its polyphe- } \\
\text { nol content and antioxidant properties. }\end{array}$ & $\begin{array}{c}\text { Dare et al., } \\
2012\end{array}$ \\
\hline $\begin{array}{l}\text { Adansonia } \\
\text { digitata }\end{array}$ & $\begin{array}{c}\text { Malvace- } \\
\text { ae }\end{array}$ & $\begin{array}{c}\text { aqueous } \\
\text { extract }\end{array}$ & $\begin{array}{c}\text { Male Wistar } \\
\text { rats }\end{array}$ & Different doses & $\begin{array}{c}\text { The cadmium chloride-treated group } \\
\text { plus A. digitata caused a significant } \\
\text { decrease in MDA levels with a signifi- } \\
\text { cant increase in antioxidant activity and } \\
\text { biochemical enzymes. The aqueous } \\
\text { extract of A. digitata seems to have a } \\
\text { healing effect against testicular damage } \\
\text { caused by cadmium chloride. This can } \\
\text { be attributed to the presence of a poly- } \\
\text { phenolic compound. }\end{array}$ & $\begin{array}{c}\text { Olaniyan et al., } \\
2021\end{array}$ \\
\hline
\end{tabular}

used organs, participants, intervention protocol, and the important findings. Also, the active ingredients of these herbs plus their chemical and molecular formula are listed in Table 2.

\section{DISCUSSION}

Having children is one of the concerns of every couple after marriage, when it does not happen, it causes concerns for the couple and their families. Due to the support of the World Health Organization for maintaining public health and reproductive health, today the use of medicinal plants as a substitute or supplement to synthetic drugs affecting fertility is considered. This is a systematic study of Iranian medicinal plants effective in the treatment of male infertility.

Recent studies have shown that, under physiological conditions, reactive oxygen species play a very important role in the intracellular messaging processes. On the other hand, over the past decade, reactive oxygen species have been implicated in the development of male infertility due to their overproduction or a reduced ability of the reproductive system and sperm to deal with it. In pathological conditions, reactive oxygen species cause male infertility through impaired spermatogenesis, sperm function and structure, motility, viability, acrosome reaction, spermovum mating, and even reduced fertilization and implantation (Dare et al., 2021; Bentrad et al., 2017; Fanaei et al., 2013).

There is a growing demand for herbal medicines around the world. Studies have shown that some medicinal plants may have fertility-enhancing properties in men by improving antioxidant activity, prevent the formation of free radicals and lipid peroxidation, and reduce oxidative stress, preventing damage to sperm cells (Moher et al., 2009). They also increase the number of testicular vessels, the lifespan and number of sperm, increasing sperm quality and protecting germ cells. On the other hand, these plants can enhance the activity of the hypothalamic-pituitary-gonadal axis on different levels, affecting the secretion of LH and testosterone (Oi et al., 2001; Ralebona et al., 2012). These medicinal plants affect male fertility, parameters such as sperm survival and mortality, pituitary hormone levels, histological changes in the testes and sperm depletion. Therefore, these herbs can help improve sperm parameters in infertile men, but this requires further clinical studies.
Some herbs inhibit the uptake of 5 alpha-reductase (a factor that converts testosterone into dihydrotestosterone), reducing gonadotropins and testosterone, increasing the affinity for sex-specific proteins, thickening the basement membrane, reducing germinal epithelial cells and reducing the irregular placement of these cells, reducing sperm count, motility, and sperm viability, but causing side effects such as infertility, at certain doses (Roozbeh et al., 2016). Some plants, such as garlic, inhibit the enzyme caspase 3 and cytochrome P450 2E1 (CYP2E1), which have a toxic effect on the testes, reducing testicular function and improving spermatogenesis by reducing these two enzymes (Vickers, 2017). Garcinia cola polyphenolic sections showed prophylactic effects on the histology and hormones of the pituitary-testicular axis of male Wistar rats (Omotola et al., 2017). Another study from Nigeria found that an injection of Cissus populnea root into male Wistar rats increased the secretion of male sex hormones such as testosterone and gonadotropins, thereby increasing the fertility of these rats (Olaolu et al., 2018). Similarly, Cocos nucifera water improved reproductive indices in Wistar rats (Kunle-Alabi et al., 2014). A study conducted in Iraq showed that Cyperus esculentus has a protective effect on testicular and sperm abnormalities caused by lead acetate in Wistar rats (Al-Shaikh et al., 2013). The aqueous extract of Cyperus esculentus, administered to Wistar rats for nine weeks, increased testicular and epididymal weight, increased sperm count and motility. These studies show that the medicinal properties of these plants are related to polyphenolic components, especially flavonoids, which can neutralize free radicals - the source of oxidative stress (Methorst \& Huyghe, 2014). Flavonoids in plant samples have antioxidant power and can optimize the function of the body's antioxidant system. Reactive oxygen species are produced in a chain of reactions that alter male reproductive cells quantitatively and qualitatively; antioxidants act by interrupting these chain reactions (Methorst \& Huyghe, 2014). In Iranian herbal medicine, many medicinal plants are used to treat various disorders and diseases. One of the most important reasons for the effectiveness of medicinal plants is the presence of effective medicinal substances (Solati et al., 2021; Bahmani et al., 2020; Aidy et al., 2020; Karimi et al., 2019; Abbasi et al., 2016; 2020). The effect of medicinal plants on sperm production and testosterone is due to the presence of secondary medicinal compounds. According to researchers, methods for standardizing medicinal plants, quality control, information on 


\begin{tabular}{|c|c|c|c|}
\hline Scientific Name & $\begin{array}{l}\text { The Most Bioactive } \\
\text { Compound }\end{array}$ & Chemical Formula & Molecular Structure \\
\hline Apium graveolens & Apigenin & $\mathrm{C}_{15} \mathrm{H}_{10} \mathrm{O}_{5}$ & \\
\hline Cinnamomum camphora & Camphor (2-bornanon) & $\mathrm{C}_{10} \mathrm{H}_{16} \mathrm{O}$ & \\
\hline Cornus mas & $\begin{array}{c}\text { Pelargonidin } \\
\text { (Olaniyan et al., 2018) }\end{array}$ & $\begin{array}{c}\text { Pelargonidin } \\
\text { (Olaniyan et al., 2018) }\end{array}$ & \\
\hline Satureja khuzestanica & Carvacrol (Dare et al., 2014) & $\mathrm{C}_{10} \mathrm{H}_{14} \mathrm{O}$ & \\
\hline Withania somnifera & withaferin A & $\mathrm{C}_{28} \mathrm{H}_{38} \mathrm{O}_{6}$ & \\
\hline Fumaria parviflora & Protopine (Dare et al., 2012) & $\mathrm{C}_{20} \mathrm{H}_{19} \mathrm{NO}_{5}$ & \\
\hline zingiber officinale & $\begin{array}{c}\text { Gingerol } \\
\text { (Olaniyan et al., 2021) }\end{array}$ & $\mathrm{C}_{17} \mathrm{H}_{26} \mathrm{O}_{4}$ & \\
\hline cinnamomum zeylanicum & $\begin{array}{l}\text { Cinnamaldehyde } \\
\text { (Dare et al., 2021) }\end{array}$ & $\mathrm{C}_{9} \mathrm{H}_{8} \mathrm{O}$ & \\
\hline Phoenix dactylifera & $\begin{array}{c}\text { Oleic acid } \\
\text { (Bentrad et al., 2017) }\end{array}$ & $\mathrm{C}_{18} \mathrm{H}_{34} \mathrm{O}_{2}$ & \\
\hline
\end{tabular}


safety and effectiveness are needed to properly understand the use of herbal medicines. Finally, we recommend more experimental and clinical studies using modern scientific principles and methods in this field.

\section{CONCLUSION}

Plants can probably be useful in increasing fertility due to their antioxidant power and lower side effects. The use of medicinal plants with the property of enhancing male fertility can be used as a substitute or supplement to chemical drugs that affect male fertility. On the other hand, it is recommended that plants with fertility reduction properties be used less or not at all in men with infertility disorders.

\section{ACKNOWLEDGEMENTS}

The authors would like to acknowledge the Shahrekord University of Medical Sciences, Shahrekord, Iran, for supporting this study.

\section{Author Contributions}

All the authors contributed equally to the writing of the first draft of the article (Shakiba Nasiri Boroujeni ${ }^{1 a}$, Farid Ansari Malamiri2a: a Please note that these authors considered as first author).

\section{CONFLICT OF INTEREST}

The authors declare no conflict of interest, financial or otherwise.

\author{
Corresponding author: \\ Emadoddin Moudi \\ Department of Urology \\ Cancer Research Center \\ Health Research Institute \\ Babol University of Medical Sciences \\ Babol Iran \\ E-mail: emadmoudi@gmail.com
}

\section{REFERENCES}

Abbasi N, Khosravi A, Aidy A, Shafiei M. Biphasic Response to Luteolin in MG-63 Osteoblast-Like Cells under High Glucose-Induced Oxidative Stress. Iran J Med Sci. 2016;41:118-25. PMID: 26989282

Abbasi N, Khalighi Z, Eftekhari Z, Bahmani M. Extraction and phytoanalysis of chemical compounds of Eucalyptus globulus leaf native to Dehloran, Ilam province, Iran by HS-SPME and GC-MS. Adv Anim Vet Sci. 2020;8:647-52. DOI: $10.17582 /$ journal.aavs/2020/8.6.647.652

Abdi F, Roozbeh N, Mortazavian AM. Effects of date palm pollen on fertility: research proposal for a systematic review. BMC Res Notes. 2017;10:363. PMID: 28764804 DOI: $10.1186 / \mathrm{s} 13104-017-2697-3$

Agarwal A, Prabakaran S, Allamaneni SS. Relationship between oxidative stress, varicocele and infertility: a meta-analysis. Reprod Biomed Online. 2006;12:630-3. PMID: 16790111 DOI: $10.1016 / S 1472-6483(10) 61190-X$

Agarwal A, Rana M, Qiu E, AlBunni H, Bui AD, Henkel R. Role of oxidative stress, infection and inflammation in male infertility. Andrologia. 2018;50:e13126. PMID: 30569652 DOI: $10.1111 /$ and.13126
Aidy A, Karimi E, Ghaneialvar H, Mohammadpour S, Abbasi N. Protective effect of Nectaroscordum tripedale extract and its bioactive component tetramethylpyrazine against acetaminophen-induced hepatotoxicity in rats. Adv Tradit Med. 2020;20:471-7. DOI: 10.1007/s13596-020-00431-z

Al-Shaikh MN, Wahab TALA, Kareem SHA, Hamoudi SR. Protective effect of Chufa Tubers (Cyperus esculentus) on induction of sperm abnormalities In mice treated with lead acetate. Int J Drug Dev Res. 2013;5:387-92.

Bahmani M, Jalilian A, Salimikia I, Shahsavari S, Abbasi N. Phytochemical screening of two Ilam native plants Ziziphus nummularia (Burm.f.) Wight \& Arn. And Ziziphus spina-christi (Mill.) Georgi using HS-SPME and GC-MS spectroscopy. Plant Sci Today. 2020;7:275-80. DOI: 10.14719/ pst.2020.7.2.714

Bastampoor F, Sadeghi H, Hosseini SE. The Petroselinum crispum L. hydroalcoholic extract effects on pituitary- gonad axis in adult Rats. Armaghane Danesh. 2014;19:30513.

Bentrad N, Gaceb-Terrak R, Benmalek Y, Rahmania F. Studies on chemical composition and antimicrobial activities of bioactive molecules from Date Palm (PHOENIXDACTYLIFERAL.) pollens and seeds. Afr J Tradit Complement Altern Med. 2017; 14:242-56. PMID: 28480436 DOI: 10.21010/ ajtcam.v14i3.26

Chyou PH, Nomura AM, Stemmermann GN, Hankin JH. A prospective study of alcohol, diet, and other lifestyle factors in relation to obstructive uropathy. Prostate. 1993;22:25364. PMID: 7683816 DOI: 10.1002/pros.2990220308

Csupor-Löffler B, Hajdú Z, Zupkó I, Réthy B, Falkay G, Forgo $P$, Hohmann J. Antiproliferative effect of flavonoids and sesquiterpenoids from Achillea millefolium s.I. on cultured human tumour cell lines. Phytother Res. 2009;23:672-6. PMID: 19107850 DOI: $10.1002 /$ ptr.2697

Dare BJ, Chukwu RO, Oyewopo AO, Makanjuola VO, Olayinka PO, Akinrinade ID, Olaniyan TO, Omotoso OD, Shafe MO, Ogundele OM, Beremako OO, Adeh MN. Histological integrity of the testis of adult wistar rats (Rattus novergicus) Treated with Garcinia kola. Reprod Syst Sex Disord. 2012;1:113. DOI: 10.4172/2161-038X.1000113

Dare BJ, Oyeniyi F, Olaniyan O. Role of antioxidant in testicular integrity. Annu Res Rev Biol. 2014;4:998-1023. DOI: $10.9734 / A R R B / 2014 / 4453$

Dare BJ, Olaniyan OT, Oyeniyi OI, Okotie GE, Lawal IA, Eweoya O. Aqueous extract of Adansonia digitata prevents Cadmium Chloride-induced testicular damage in Wistar Rats. J Basic Clin Physiol Pharmacol. 2021. Epub ahead of print. PMID: 33705611 DOI: 10.1515/jbcpp-2020-0222

De Rosa G, Corsello SM, Ruffilli MP, Della Casa S, Pasargiklian E. Prolactin secretion after beer. Lancet. 1981;2:934. PMID: 6117712 DOI: 10.1016/S0140-6736(81)91422-7

Dorostghoal M, Seyyednejad SM, Jabari A. Protective effects of Fumaria parviflora L. on lead-induced testicular toxicity in male rats. Andrologia. 2014;46:437-46. PMID: 23611729 DOI: $10.1111 /$ and. 12100 
Fallahi S, Rajaei M, Malekzadeh K, Kalantar SM. Would Phoenix Dactyflera Pollen (palm seed) be considered as a treatment agent against Males' infertility? A systematic review. Electron Physician. 2015;7:1590-6. PMID: 26816585 DOI: $10.19082 / 1590$

Fanaei $H$, Azizi $Y$, Khayat $S$. A review: role of oxidative stress in male infertility. JABS. 2013;3:93-103.

Godmann M, Lambrot R, Kimmins S. The dynamic epigenetic program in male germ cells: Its role in spermatogenesis, testis cancer, and its response to the environment. Microsc Res Tech. 2009;72:603-19. PMID: 19319879 DOI: 10.1002/jemt.20715

Gupta S, Agarwal A, Banerjee J, Alvarez JG. The role of oxidative stress in spontaneous abortion and recurrent pregnancy loss: a systematic review. Obstet Gynecol Surv. 2007;62:335-47. PMID: 17425812 DOI: 10.1097/01. ogx.0000261644.89300.df

Haeri S, Minaie B, Amin G, Nikfar S, Khorasani R, Esmaily $H$, Salehnia A, Abdollahi M. Effect of Satureja khuzestanica essential oil on male rat fertility. Fitoterapia. 2006;77:4959. PMID: 16889906 DOI: 10.1016/j.fitote.2006.05.025

Hasani-Ranjbar S, Larijani B, Abdollahi M. A systematic review of the potential herbal sources of future drugs effective in oxidant-related diseases. Inflamm Allergy Drug Targets. 2009;8:2-10. PMID: 19275687 DOI: $10.2174 / 187152809787582561$

Hosseini $\mathrm{H}$, Abdi F. Experiences of vasectomy: a phenomenological study. N Am J Med Sci. 2012;4:619-23. PMID: 23272302 DOI: $10.4103 / 1947-2714.104311$

Hu L, Xu HM, Xiong JW, Tian YH, Ming Y, Xiong F, Xiong CL. Resistant effect of water decoction of root of Crataegus cuneata on male infertility induced by GTW in rats. Zhongguo Zhong Yao Za Zhi. 2006;31:1521-5. PMID: 17144471

Jain S, Choudhary GP, Jain DK. Medicinal plants with potential anti-fertility activity: A review. Int J Green Pharm. 2015;9:223-8.

Jiang D, Coscione A, Li L, Zeng BY. Effect of Chinese Herbal Medicine on Male Infertility. Int Rev Neurobiol. 2017;135:297-311. PMID: 28807164 DOI: 10.1016/ bs.irn.2017.02.014

Kachroo M, Agrawal S. Anti-implantation activity of different extract of the peels of citrus medica, Linn. Int J Pharm Tech Res. 2011;3:535-9.

Karimi E, Abbasi S, Abbasi N. Thymol polymeric nanoparticle synthesis and its effects on the toxicity of high glucose on OEC cells: involvement of growth factors and integrin-linked kinase. Drug Des Devel Ther. 2019;13:2513-32. PMID: 31440034 DOI: 10.2147/DDDT.S214454

Kesari KK, Agarwal A, Henkel R. Radiations and male fertility. Reprod Biol Endocrinol. 2018;16:118. PMID: 30445985 DOI: $10.1186 / \mathrm{s} 12958-018-0431-1$

Khaki A, Khaki AA, Hajhosseini L, Golzar FS, Ainehchi N. The anti-oxidant effects of ginger and cinnamon on spermatogenesis dys-function of diabetes rats. Afr J Tradit Complement Altern Med. 2014;11:1-8. PMID: 25392573 DOI: 10.4314 /ajtcam.v11i4.1
Kim SJ, Kim MR, Hwang SY, Bae WJ, Kim S, Hong SH, Lee JY, Hwang TK, Wang Z, Kim SW. Preliminary report on the safety of a new herbal formula and its effect on sperm quality. World J Mens Health. 2013;31:254-61. PMID: 24459660 DOI: $10.5534 /$ wjmh.2013.31.3.254

Kooti W, Mansouri E, Ghasemiboroon M, Harizi M, AshtaryLarky D, Afrisham R. The Effects of Hydroalcoholic Extract of Apium graveolens Leaf on the Number of Sexual Cells and Testicular Structure in Rat. Jundishapur J Nat Pharm Prod. 2014;9:e17532. PMID: 25625050 DOI: 10.17795/ jjnpp-17532

Kunle-Alabi OT, Akindele OO, Oyovwi MO, Duro-Ladipo MA, Raji Y. Cocos nucifera L. water improves reproductive indices in Wistar Rats. Afr J Med Med Sci. 2014;43:305-13. PMID: 26234118

Low BS, Das PK, Chan KL. Standardized quassinoid-rich Eurycoma longifolia extract improved spermatogenesis and fertility in male rats via the hypothalamic-pituitary-gonadal axis. J Ethnopharmacol. 2013;145:706-14. PMID: 23261482 DOI: 10.1016/j.jep.2012.11.013

Ma B, Qi H, Li J, Xu H, Chi B, Zhu J, Yu L, An G, Zhang Q. Triptolide disrupts fatty acids and peroxisome proliferator-activated receptor (PPAR) levels in male mice testes followed by testicular injury: A GC-MS based metabolomics study. Toxicology. 2015;336:84-95. PMID: 26219505 DOI: $10.1016 /$ j.tox.2015.07.008

Marbeen MI, Al-Snafi AE, Marbut MM, Allahwerdy IY. The probable therapeutic effects of date palm pollen in thetreatment of male infertility. Tikret J Pharm Sci. 2005;1:305.

Methorst C, Huyghe E. Stress oxydant et infertilité masculine: physiopathologie et intérêt thérapeutique des antioxydants. Prog Urol. 2014;24:4-10. DOI: PUROL-09-201424-HS3-1166-7087-101019-201400269

Modaresi M, Mesripour M, Asadi Margh Maleki M, Hamedanian MK. Effect of Saffron (Crocus Sativus) extract on level of FSH, LH and testosterone in mice. J Zanjan Univ Med Sci Health Serv. 2008;16:11-7.

Moghbelinejad S, Mozdarani H, Ghoraeian P, Asadi R. Basic and clinical genetic studies on male infertility in Iran during 2000-2016: A review. Int J Reprod Biomed. 2018;16:13148. PMID: 29766145 DOI: $10.29252 /$ ijrm.16.3.131

Moher D, Liberati A, Tetzlaff J, Altman DG; PRISMA Group. Preferred reporting items for systematic reviews and meta-analyses: the PRISMA statement. PLoS Med. 2009;6:e1000097. PMID: 19621072 DOI: 10.1371/journal.pmed. 1000097

Nasimi Doost Azgomi R, Zomorrodi A, Nazemyieh H, Fazljou SMB, Sadeghi Bazargani H, Nejatbakhsh F, Moini Jazani A, Ahmadi AsrBadr Y. Effects of Withania somnifera on Reproductive System: A Systematic Review of the Available Evidence. Biomed Res Int. 2018;2018:4076430. PMID: 29670898 DOI: $10.1155 / 2018 / 4076430$

Oi Y, Imafuku M, Shishido C, Kominato Y, Nishimura S, Iwai K. Garlic supplementation increases testicular testosterone and decreases plasma corticosterone in rats fed a high protein diet. J Nutr. 2001;131:2150-6. PMID: 11481410 DOI: $10.1093 /$ jn $/ 131.8 .2150$ 
Olaniyan OT, Kunle-Alabi OT, Raji Y. Protective effects of methanol extract of Plukenetia conophora seeds and 4H-Pyran-4-One 2,3-Dihydro-3,5-Dihydroxy-6-Methyl on the reproductive function of male Wistar rats treated with cadmium chloride. JBRA Assist Reprod. 2018;22:289-300. PMID: 30106540 DOI: 10.5935/1518-0557.20180048

Olaniyan OT, Ojewale OA, Dare A, Adebayo O, Enyojo JE, Okotie GE, Adetunji CO, Mada BS, Okoli BJ, Eweoya OO. Cocos nucifera L. oil alleviates lead acetate-induced reproductive toxicity in sexually-matured male Wistar rats. J Basic Clin Physiol Pharmacol. 2021. Epub ahead of print. PMID: 33713589 DOI: 10.1515/jbcpp-2020-0281

Olaolu TD, Rotimi DE, Olaolu AP. Effect of alcohol infusion of Cissus populnea root on testicular function and serum hormone of male Wistar rats. Asian Pac J Reprod 2018;7:117-22. DOI: $10.4103 / 2305-0500.233572$

Omotola MB, Adeosun IO, Obuotor EM, Akomolafe RO, Ayannuga OA. Assessment of the Effects of Graded Doses of Polyphenolic-Rich Fraction of Garcinia kola Seeds on Pituitary-Testicular Axis of Male Wistar Rats. Dose Response. 2017;15:1559325817729260. PMID: 29051716 DOI: $10.1177 / 1559325817729260$

Oyeyemi MO, Olukole SG, Esan O. Sperm morphological studies of West African Dwarf Bucks treated with pumpkin plant (Cucurbita pepo). Int J Morphol. 2008;26:121-6. DOI: $10.4067 /$ S0717-95022008000100020

Ralebona N, Sewani-Rusike CR, Nkeh-Chungag BN. Effects of ethanolic extract of Garcinia kola on sexual behaviour and sperm parameters in male Wistar rats. Afr J Pharm Pharmacol. 2012;6:1077-82. DOI: 10.5897/AJPP11.652

Rezvanfar M, Sadrkhanlou R, Ahmadi A, Shojaei-Sadee H, Rezvanfar M, Mohammadirad A, Salehnia A, Abdollahi $M$. Protection of cyclophosphamide-induced toxicity in reproductive tract histology, sperm characteristics, and DNA damage by an herbal source; evidence for role of free-radical toxic stress. Hum Exp Toxicol. 2008;27:901-10. PMID: 19273545 DOI: $10.1177 / 0960327108102046$

Roozbeh N, Rostami S, Abdi F. A review on herbal medicine with fertility and infertility characteristics in males. Iran ] Obstet Gynecol Infertil. 2016;19:18-32 DOI: 10.22038/ IJOGI.2016.7278

Safarnavadeh T, Rastegarpanah M. Antioxidants and infertility treatment, the role of Satureja Khuzestanica: A mini-systematic review. Iran J Reprod Med. 2011;9:61-70. PMID: 25587249
Shahabi S, Jorsaraei SG, Akbar Moghadamnia A, Barghi E, Zabihi E, Golsorkhtabar Amiri M, Maliji G, Sohan Faraji A, Abdi Boora M, Ghazinejad N, Shamsai H. The effect of camphor on sex hormones levels in rats. Cell J. 2014;16:231-4. PMID: 24567939

Sharpe RM, Franks S. Environment, lifestyle and infertility--an inter-generational issue. Nat Cell Biol. 2002;4:3340. PMID: 12479613 DOI: $10.1038 / n c b-n m-f e r t i l i t y S 33$

Singh GK, Jemal A. Socioeconomic and Racial/Ethnic Disparities in Cancer Mortality, Incidence, and Survival in the United States, 1950-2014: Over Six Decades of Changing Patterns and Widening Inequalities. J Environ Public Health. 2017;2017:2819372. PMID: 28408935

Solati K, Karimi M, Rafieian-Kopaei M, Abbasi N, Abbaszadeh S, Bahmani M. Phytotherapy for Wound Healing: The Most Important Herbal Plants in Wound Healing Based on Iranian Ethnobotanical Documents. Mini Rev Med Chem. 2021;21:500-19. PMID: 33213344 DOI: 10.2174/138955 7520666201119122608

Vickers NJ. Animal Communication: When I'm Calling You, Will You Answer Too? Curr Biol. 2017;27:R713-5. PMID: 28743020 DOI: $10.1016 /$ j.cub.2017.05.064

Wang SC, Wang SC, Li CJ, Lin CH, Huang HL, Tsai LM, Chang $\mathrm{CH}$. The Therapeutic Effects of Traditional Chinese Medicine for Poor Semen Quality in Infertile Males. J Clin Med. 2018;7:239. PMID: 30149532 DOI: 10.3390/jcm7090239

Zarei L, Sadrkhanlou R, Shahrooz R, Malekinejad H, Eilkhanizadeh B, Ahmadi A. Protective effects of vitamin E and Cornus mas fruit extract on methotrexate-induced cytotoxicity in sperms of adult mice. Vet Res Forum. 2014;5:21-7. PMID: 25568688

Zarei L, Shahrooz R. Protective effects of Cornus mas fruit extract on methotrexate-induced alterations in mice testicular tissue: Evidences for histochemical and histomorphometrical changes in an animal model study. Vet Res Forum. 2019;10:307-13. PMID: 32206226 DOI: 10.30466/vrf.2019.69516.1955

Zhang K, Fu L, An Q, Hu W, Liu J, Tang X, Ding Y, Lu W, Liang $X$, Shang $X$, Gu Y. Effects of Qilin pills on spermatogenesis, reproductive hormones, oxidative stress, and the TSSK2 gene in a rat model of oligoasthenospermia. BMC Complement Med Ther. 2020;20:42. PMID: 32046715 DOI: $10.1186 / \mathrm{s} 12906-019-2799-7$

Zhou SH, Deng YF, Weng ZW, Weng HW, Liu ZD. Traditional Chinese Medicine as a Remedy for Male Infertility: A Review. World J Mens Health. 2019;37:175-85. PMID: 30644235 DOI: 10.5534/wjmh. 180069 